\title{
KONKURENCYJNOŚĆ A PRAKTYKA DZIAŁAŃ CHIŃSKICH PRODUCENTÓW SAMOCHODÓW ELEKTRYCZNYCH NA RYNKU EUROPEJSKIM
}

Konkurencja na rynku klasycznych samochodów osobowych jest dobrze znana i opisana, a rynek zdominowany przez graczy funkcjonujących na nim od wielu lat. Zainteresowanie ochroną środowiska związane bezpośrednio z ochroną zasobów naturalnych sprawia, że konkurencja przenosi się na pole producentów samochodów elektrycznych, którzy w tym obszarze poszukują przewagi, aby odnieść sukces rynkowy. Wiele różnych działań podejmują chińscy producenci samochodów elektrycznych, próbujący zdobyć rynek europejski.

Celem artykułu jest ocena ich szans na zaistnienie na tym rynku. Analiza ta ma pomóc w uzyskaniu odpowiedzi na pytanie, czy możliwe jest zdominowanie europejskiego rynku samochodów elektrycznych przez chińskich producentów w oparciu o swoje przewagi konkurencyjne.

Aby zrealizować założony cel, posłużono się metodą analizy i syntezy w zakresie problematyki konkurencyjności oraz przewagi konkurencyjnej. Wykorzystano również metodę studium przypadku, odnosząc się do praktyki chińskich producentów samochodów na rynku w Chinach i Europie. Tłem dla tych działań są dane statystyczne obrazujące światowy rynek samochodowy w zakresie samochodów spalinowych i elektrycznych.

Zebrany i usystematyzowany materiał prowadzi do wniosku, że chińscy producenci doskonale wiedzą, na czym budować konkurencyjność w Europie, a także jak zdobywać i utrzymywać obszary przewagi konkurencyjnej. Ich wieloletnie doświadczenia zdobyte we współpracy z czołowymi europejskimi koncernami samochodowymi, duże zasoby kapitałowe oraz konieczność ekspansji zagranicznej powodują, że stają się kluczowymi graczami wśród producentów samochodowych w Europie. Zakup udziałów czy wykup niektórych europejskich producentów samochodów sprawia, że trwała obecność chińskich producentów samochodów elektrycznych w Europie staje się faktem. Po latach nauki przyszedł czas 
ekspansji, która - jak pokazują zebrane dane - spełnia wszelkie przesłanki, aby zakończyć się sukcesem.

\section{Konkurencyjność i przewaga konkurencyjna - aspekt teoretyczny}

Aby zrozumieć, na czym polega przewaga konkurencyjna, trzeba wyjść od zdefiniowania i opisania konkurencyjności przedsiębiorstw. W literaturze przedmiotu brak jednoznacznej i akceptowanej przez wszystkich badaczy definicji tego terminu.

Marek Stankiewicz definiuje konkurencyjność jako „zdolność do sprawnego realizowania celów na rynkowej arenie konkurencji”". Sprawność w tej definicji rozumiana jest jako jednoczesne występowanie trzech głównych czynników: skuteczności, korzyści i ekonomiczności. W przedstawionym podejściu priorytetowe znaczenie ma potencjał firmy, umiejętne zarządzanie zasobami oraz pozycja przedsiębiorstwa, określona jako wynik konkurowania. Autor wyznaczył także kryteria klasyfikacji konkurencyjności, wymieniając wśród nich m.in. przedział i moment oceny, obszar występowania, strony relacji rynkowych oraz poziom konkurencyjności ${ }^{2}$.

Dla Zdzisława Pierścionka istotne znaczenie dla stworzenia skutecznej strategii konkurencji mają czynniki decydujące o wyborze przez konsumenta konkretnej oferty. Do priorytetowych rynkowych determinant konkurencyjności przedsiębiorstw zalicza m.in. funkcję i jakość oferowanego produktu, stopień wyróżnienia się produktu i firmy na tle konkurentów, intensywność i jakość promocji oraz markę i renomę firmy. Całościowo czynniki te tworzą określoną wartość dla docelowego odbiorcy, umacniając tym samym pozycję przedsiębiorstwa i czyniąc je konkurencyjnym ${ }^{3}$.

Eulalia Skawińska konkurencyjność przedsiębiorstw określa jako proces polegający na dążeniu do realizacji interesów za pomoca przedstawienia korzystniejszych od konkurentów ofert ceny, jakości lub innych elementów mających znaczenie przy zawieraniu transakcji. Autorka tłumaczy to pojęcie jako długookresową zdolność do zrównoważonego rozwoju, relatywną umiejętność forsowania własnych wartości czy systemu celów oraz zdolność do wzrostu efektywności przedsiębiorstwa. Konkurencyjność w tym rozumieniu jest utożsamiana z rywalizacją i współpraca, której efektem jest określenie bieżących potrzeb klientów i poznanie nowych technologii ${ }^{4}$.

Analizowane dotychczas podejścia dotyczące konkurowania przedsiębiorstw mają bezpośredni związek z uzyskiwaniem przez nie strategicznej pozycji na rynku,

1 M.J. Stankiewicz, Konkurencyjność przedsiębiorstwa. Budowanie konkurencyjności przedsiębiorstwa w warunkach globalizacji, Torun 2002, s. 36 .

2 Ibidem, s. 36-44.

3 Z. Pierścionek, Strategie konkurencji i rozwoju przedsiębiorstwa, Warszawa 2003, s. 169.

4 J. Wiśniewska, K. Janasz, Innowacje i jakosśc w zarzqdzaniu organizacjami, Warszawa 2013, s. 20 , za: Konkurencyjnośćprzzedsiębiorstw - nowe podejście, red. E. Skawińska, Warszawa-Poznań 2002, s. 76. 
co wiąże się ze zdobyciem przewagi konkurencyjnej. Istota przewagi konkurencyjnej przedsiębiorstw jest „sposób tworzenia wartości dodanej za pomocą konfiguracji zasobów (które przedsiębiorstwo rozwija), rodzajów działalności gospodarczej (w jakich przedsiębiorstwo konkuruje), a także infrastruktury menedżerskiej, której zadaniem jest ożywienie całości”' . Akcent jest tutaj położony na efektywne zarządzanie, wysoką jakość zasobów oraz zdolność realizowania procesów. Umiejętne zespolenie posiadanych zasadniczych zasobów z odpowiednią organizacją wywołuje efekt synergiczny, prowadzacy do osiagnięcia zadowalającego poziomu koordynacji w długim okresie.

Wielowymiarowość przedstawionej definicji pokazuje, jak trudno jednoznacznie wyjaśnić pojęcie przewagi konkurencyjnej. Próbę syntetycznego ujęcia tego terminu podjął Jerzy Rokita, według którego jest to „zdolność do takiego wykorzystania zasobów i warunków konkurowania na rynkach zaopatrzenia i zbytu produktów, które umożliwiają wytwarzanie większej wartości dodanej dla przedsiębiorstwa oraz jego faktycznych i potencjalnych klientów niż wartości dodane generowane przez konkurentów". Zatem można uznać, że determinanta konkurencyjności przedsiębiorstwa jest wysoka zdolność osiagania celów w warunkach narastającej konkurencji, natomiast umiejętność konkurowania określona jest poprzez ciagłe doskonalenie przystosowania zasobów do coraz to nowych wyzwań, takich jak nowe technologie czy produkty.

Wiesław Grudzewski i Irena Hejduk uznali, że przewagę konkurencyjną kreuje wartość dodana, mająca wpływ na osiagane wyniki finansowe oraz wzrost zysku. Aby osiagnąć przewagę, należy nieustannie analizować transformacje zarówno ekonomiczne, jak i technologiczne na rynku. Kolejnymi kluczowymi elementami są odpowiednie reakcje na zmiany oczekiwań klientów oraz udoskonalenie systemu komunikacji z odbiorcą i dostawcą?.

George Stonehouse, Jim Hamill, David Campbell i Tony Purdie w celu zdefiniowania przewagi konkurencyjnej posłużyli się powiązanymi ze sobą koncepcjami. Pierwszą z nich są lepsze wyniki, określone ogólnie jako wyższy udział w rynku, ponadprzeciętne zyski, niższe koszty jednostkowe czy zwroty z inwestycji. Kolejnym elementem jest strategia, czyli uporządkowany plan działania, który umożliwi osiagnięcie przewagi konkurencyjnej. Istotne są również kluczowe kompetencje bądź umiejętności wyróżniające, które będą czynnikiem określającym pozycję organizacji. Autorzy ci wskazali też konfigurację, rozumianą jako geograficznie skoncentrowane lub rozproszone skonfigurowanie działań przedsiębiorstwa, dążące do

5 D.J. Collis, C.A. Montgomery, Creating corporate advantage, „Harvard Business Review” 1998, vol. 76 , issue 3 , s. $71-83$.

6 J. Rokita, Zarzadzanie strategiczne: tworzenie $i$ utraymywanie przewagi konkurencyjnej, Warszawa 2005, s. 57-61.

7 W.M. Grudzewski, I.K. Hejduk, Metody projektowania systemów zarz̨qdzania, Warszawa 2004, s. 8,9 . 
uzyskania określonej wartości dodanej w układzie międzynarodowym. Do ostatnich elementów zaliczyli koordynację oraz zdolność reakcji na zmiany, w szczególności o charakterze gwałtownym ${ }^{8}$.

Krzysztof Obłój twierdzi, że osiagnięcie przewagi konkurencyjnej wymaga unikalnego sposobu działania, zapewniającego nadzwyczajne rezultaty. Powinna ona mieć charakter temporalny - niezależnie czy istnieje w dłuższym okresie, czy w krótszym, zawsze ma czasowy wymiar. Czas utrzymywania wyższej pozycji zależny jest natomiast od zachowań konkurencji. Drugim fundamentalnym elementem przewagi jest lokalność interpretowana jako rynek o jasno wyznaczonych granicach. Bez ich dokładnego określenia niemożliwe jest wnikliwe określenie potrzeb odbiorców i działań konkurenciji?

Według Wojciecha Wrzoska przewaga konkurencyjna przedsiębiorstwa związana jest z jego korzystniejszym usytuowaniem na rynku w porównaniu z usytuowaniem konkurentów, co jednak nie przesądza jeszcze o możliwości osiagania przez nie przewagi konkurencyjnej. Jest ono jedynie przesłanką jej osiagania ${ }^{10}$.

\section{Obszary przewagi konkurencyjnej}

Ze względu na wielowymiarowy charakter przewagi konkurencyjnej w literaturze występuje też wiele różnych podejść dotyczących tego zjawiska. Joanna Bednarz, opisując kształtowanie się przewagi konkurencyjnej, wyodrębnia trzy podejścia: 1) teorie klasyczne - źródła zewnętrzne odnoszące się do otoczenia zewnętrznego badanego podmiotu gospodarczego, 2) nowe koncepcje - źródła wewnętrzne, opierające się na zasobach przedsiębiorstwa, 3) połączenie źródeł wewnętrznych i zewnętrznych ${ }^{11}$.

Obecnie zbudowanie przewagi konkurencyjnej koncentrujące się wyłącznie na teoriach klasycznych jest trudne, a wręcz niemożliwe. Stale zmieniające się otoczenie rynkowe, ogromna konkurencja oraz coraz to nowe wymagania powoduja, że opieranie się na koncepcjach tradycyjnych jest niewystarczające. Ze względu na niedostateczne wyjaśnienie mechanizmu tworzenia przewagi konkurencyjnej za pomocą koncepcji klasycznych zaczęto rozwijać umiejętności oraz bardziej złożone metody pozyskiwania zasobów, tworząc nowe teorie. Powodem stworzenia nowo-

${ }^{8}$ G. Stonehouse, J. Hamill, D. Campbell, T. Purdie, Globalizacja. Strategia i zarzadzanie, thum. M. Albigowski, Warszawa 2001, s. 94.

9 K. Obłój, Pasja i dyscyplina strategii: jak z. marzeñ i decyzji zbudować sukces firmy, Warszawa 2016, s. $125,126$.

10 W. Wrzosek, Præewaga konkurencyjna, „Marketing i Rynek” 1999, nr 7, s. 2.

$11 \mathrm{~J}$. Bednarz, Konkurencyjnośćpolskich przedsiębiorstw na rynkach europejskich na prayktadzie wybranych branங், Gdańsk 2013, s. 144. 
czesnych koncepcji był także zmieniający się charakter konkurencji z lokalnej do międzynarodowo-globalnej. Od teorii klasycznej różni je występowanie szeroko pojętej współpracy. Przedsiębiorstwa skłonne są do tworzenia aliansów i porozumień, co umożliwia ograniczenie konkurencji. Cechą charakterystyczną jest też brak dążenia do stabilnej, długookresowej przewagi konkurencyjnej. Znaczącą rolę odgrywaja posiadane przez przedsiębiorstwo zasoby (materialne - zasoby naturalne, kapitał itp. i niematerialne - wiedza, rozwiązania technologiczne itp.) oraz wykorzystanie wewnętrznych predyspozycji. Ewolucja poglądów przyczyniła się do wzrostu znaczenia kluczowych kompetencji, interpretowanych jako połączenie wiedzy, umiejętności oraz zasobów strategicznych. Kluczowe, niepowtarzalne kompetencje pozwalaja przedsiębiorstwu na wykorzystanie zasobów w taki sposób, aby uniemożliwić bądź znacznie utrudnić konkurencji naśladownictwo, co przekłada się na stworzenie silnej pozycji rynkowej.

Zwolennicy nurtu nowoczesnego uważaja, że zdobycie przewagi konkurencyjnej jest możliwe dzięki poprawnemu rozpoznaniu i wykorzystaniu okazji, przy czym zwracają uwagę na zagrożenia ze strony konkurentów. Przedsiębiorstwa zmuszone są do działań w warunkach ciagłego, zmieniającego się otoczenia rynkowego, co wymusza na nich konieczność posiadania unikalnych kompetencji, skutecznego zarządzania i opracowania efektywnej strategii działania ${ }^{12}$.

Inne spojrzenie na sposoby podziału przewagi konkurencyjnej przedstawiaja Olaf Flak i Grzegorz Głód, wskazując przewage potencjalną oraz efektywną. Potencjalna przewaga konkurencyjna przedsiębiorstwa opiera się na zasobach należących do firmy oraz umiejętnościach, które umożliwią efektywne wykorzystanie tych zasobów w odpowiednim czasie. Można ją scharakteryzować także jako wyższość przedsiębiorstwa nad innymi konkurentami, bez uwzględniania preferencji nabywców. Natomiast przewaga efektywna powstaje wskutek konfrontacji przewagi potencjalnej z preferencjami nabywców, będąc tym samym kombinacją elementów marketingu-mix ${ }^{13}$.

Krzysztof Obłój proponuje szersze określenie koncepcji przewagi konkurencyjnej, wyróżniając cztery bazowe typy przewag: 1) naturalny, 2) relacji między ceną a jakościa, 3) systemu obsługi zwiększającego koszty zmiany, 4) systemu obsługi budującego wysokie bariery wejścia.

Za główne źródło przewagi naturalnej w wąskim ujęciu uważa się lokalizację, której uwarunkowania mają znaczący wpływ na budowanie przewagi konkurencyjnej, głównie przez wzgląd na ograniczoną mobilność odbiorców. Skuteczna strategia lokalizacyjna zapewnia przedsiębiorstwom kontrolę oraz przyczynia się do osiagnięcia spójności organizacji. Z lokalizacją ściśle związane są regulacje prawne

12 Ibidem, s. 144.

13 O. Flak, G. Głód, Konkurencyjni przetrwaja: o przedsiębiorstwie, metodach badania konkurencyjności i twoich szansach na sukeces rynkowy, Warszawa 2012, s. 147, 148. 
i dostęp do zasobów. Przewaga relacji między ceną a jakością jest bardzo istotna z ekonomicznego punku widzenia, ponieważ firma ma swobodę strategicznego wyboru, której brakuje u konkurentów. W praktyce tylko jedno przedsiębiorstwo może osiagnać dominująca pozycję, mając najniższe koszty przy danej jakości produktu. Pozostałe firmy, które nie są w stanie osiagnąć tej przewagi, są zmuszone do znalezienia innych możliwości, m.in. w rynkowych niszach. Przewaga systemu obsługi zwiększającego koszty zmiany opiera się na stałej współpracy pomiędzy dostawcą i odbiorca. Do głównych założeń można zaliczyć skrupulatny dobór odbiorców, oferowanie takiej propozycji produktu, która będzie odpowiedzią na problem konkretnego odbiorcy, uwzględniając tym samym jego potrzeby. Ostatnim aspektem jest wyjście poza rolę biernego dostawcy i skupienie się na wysokim poziomie oferowanych usług, doradztwie i regularnym badaniu potrzeb. Wprowadzanie barier wejścia do sektora wiąże się z logiką uwarunkowań naturalnych i jest w pewnym sensie zablokowaniem konkurencji możliwości działania. Z jednej strony umożliwia zbudowanie pozycji monopolistycznej, z drugiej może stać się jedynie przewaga przejściowa, jeśli rzeczywiści i potencjalni konkurenci zjednoczą swoje działania ${ }^{14}$.

\section{Źródła przewagi konkurencyjnej}

$\mathrm{Na}$ przestrzeni lat wykreowało się wiele źródeł umożliwiających zdobycie przewagi konkurencyjnej. Jednym z nich jest wspólpraca przedsiębiorstw, szerzej określana jako tworzenie relacji partnerskich, mających na celu dostarczenie jak największej wartości dla klienta po jak niższych kosztach. Fundamentalną zasadą współdziałania jest posiadanie przez partnerskie przedsiębiorstwa podobnego systemu wartości, który wynika ze zbieżnych kultur organizacyjnych. Kooperacja powinna opierać się m.in na tworzeniu wspólnych systemów informacyjnych, likwidacji powielających się czynności, redukcji kosztów czy uproszczeniu procesów biznesowych. Wymaga ona także integracji systemów informacyjnych, umożliwiającej uczestnikom stworzenie jednolitej bazy danych, wykorzystywanej np. do realizacji zleceń. Aktywne współdziałanie $\mathrm{z}$ innymi podmiotami zapewnia przedsiębiorstwom dostęp do technologii oraz wiedzy, z której nie byłyby w stanie korzystać samodzielnie. Może stanowić podstawę do osiagnięcia przewagi konkurencyjnej przedsiębiorstwa zarówno poprzez czerpanie korzyści, tj. możliwość uczenia się od partnera czy większy zakres informacji, jak i poprzez zwiększenie potencjału synergii, wynikającego $\mathrm{z}$ wzajemnej nauki ${ }^{15}$.

14 K. Obłój, Tworyywo skutecznych strategii, Warszawa 2002, s. 104-120.

15 W poszukiwaniu strategicznych przewag konkurencyjnych, red. J.L. Czarnota, M. Moszkowicz, Częstochowa 2003, s. 189, 190. 
Kolejnym źródłem przewagi konkurencyjnej są kompetencje, rozumiane jako suma zdolności, wykształcenia i doświadczenia, a także predyspozycji i unikalnych cech osobowości. Kompetencje od innych zasobów odróżnia fakt, że nie tracą one na wartości. Intensywność oraz odpowiednie predyspozycje do ich wykorzystania moga przyczynić się do zwiększenia ich wartości. Przedsiębiorstwa powinny dążyć do rozwoju nie tylko pojedynczych kompetencji, lecz do posiadania kluczowych kompetencji powstających w wyniku połączenia zróżnicowanych doświadczeń całej organizacji. Ich istotę można również przedstawić jako gromadzenie umiejętności niebędących w posiadaniu konkurentów. Jako przykład może posłużyć sfera marketingu, w której powyższe umiejętności odnoszą się do pozycjonowania produktu, precyzyjnej segmentacji rynku czy rozwoju efektywnych strategii ${ }^{16}$.

We współczesnych procesach gospodarczych obserwujemy wzrastające znaczenie zasobów niematerialnych. Jednym z kluczowych zasobów przedsiębiorstwa, decydującym o jego trwałej przewadze konkurencyjnej, jest wiedza. Jej optymalne wykorzystanie przyczynia się do tworzenia wartości dodanej, która może stać się determinantą rynkowego sukcesu. Efektywne zarządzanie wiedzą przekłada się na poprawę innowacyjności, właściwą komunikację, budowanie współpracy, umiejętność zastosowania specjalistycznej wiedzy oraz know-how czy doskonalenie zarówno na poziomie pracowników, jak i całej organizacji ${ }^{17}$. Ciagłe zmiany gospodarcze i globalizacyjne sa przyczyną narastającej konkurencji, dlatego też podmioty chcące utrzymać konkurencyjną pozycję muszą stale się rozwijać. Skuteczne działania organizacji w zakresie wiedzy powinny mieć charakter długofalowy, gdyż kluczowe jest nie tylko stosowanie wiedzy, lecz także jej systematyczne uzupełnianie ${ }^{18}$.

W kontekście koncepcji konkurencyjności i przewagi konkurencyjnej warto zwrócić uwagę, jak w tym obszarze radzą sobie chińskie przedsiębiorstwa, które próbuja zdominować rynek samochodów elektrycznych. Jest to stosunkowo nowy obszar konkurencji, budowania konkurencyjności czy szukania przewagi konkurencyjnej. Praktyka działań przedsiębiorstw chińskich pokazuje, jak bardzo zróżnicowane jest podejście do tego zagadnienia. Przedstawiony zarys teoretyczny w połączeniu ze studium przypadku oraz analizą danych statystycznych dotyczących opisywanego rynku dowodzi, że istnieje obszar, na którym chińscy producenci samochodów elektrycznych budują trwałą przewagę konkurencyjną. Istotna jest nie tylko przewaga w sferze kosztowej, ale też w zakresie wiedzy czy doświadczenia.

\footnotetext{
16 Cžnnniki i śródta przewagi konkurencyjnej, red. M. Juchniewicz, Olsztyn 2009, s. 295, 296.

17 Podejście innowacyjne w zarzadzaniu przedsiębiorstwem, red. R. Nowacki, M.W. Staniweski, Warszawa 2010 , s. $115-117$.

18 M. Soniewicki, Zarzqdzanie wiedzq a przewaga konkurencyjna przedsiębiorstwa mięzynarodowego. Ujecie teoretyczne i praktyczne, Warszawa 2017, s. 43-46.
} 


\section{Światowy rynek motoryzacyjny}

Rok 2018 był zaskakujący dla analityków śledzących światowy rynek motoryzacyjny. Po raz pierwszy od 2009 r. nastapił bowiem spadek sprzedaży samochodów osobowych. Trzeba jednak zaznaczyć, że rynek samochodowy w latach 2008-2009 doświadczył największego kryzysu w swojej historii - produkcja spadła w tym okresie o 15,5\%, osiagając poziom 61,8 mln pojazdów. W obliczu załamania z 2009 r. wiele państw wprowadziło programy złomowania samochodów oraz inne oferty mające na celu zachęcenie do kupowania nowych samochodów. Doprowadziło to do silnego odbicia rynku o 26\% (77,9 mln sztuk) w 2010 r. Rynek odzyskał swoje właściwe tempo w 2011 r., notując wzrost na poziomie 5\% (82,1 mln sztuk). Taki trend trwał przez kolejne 2 lata, uzyskując sprzedaż w wysokości 86 mln sztuk w 2013 r. Po spadku w kolejnych latach sprzedaż powróciła do tego poziomu dopiero w roku 2017.

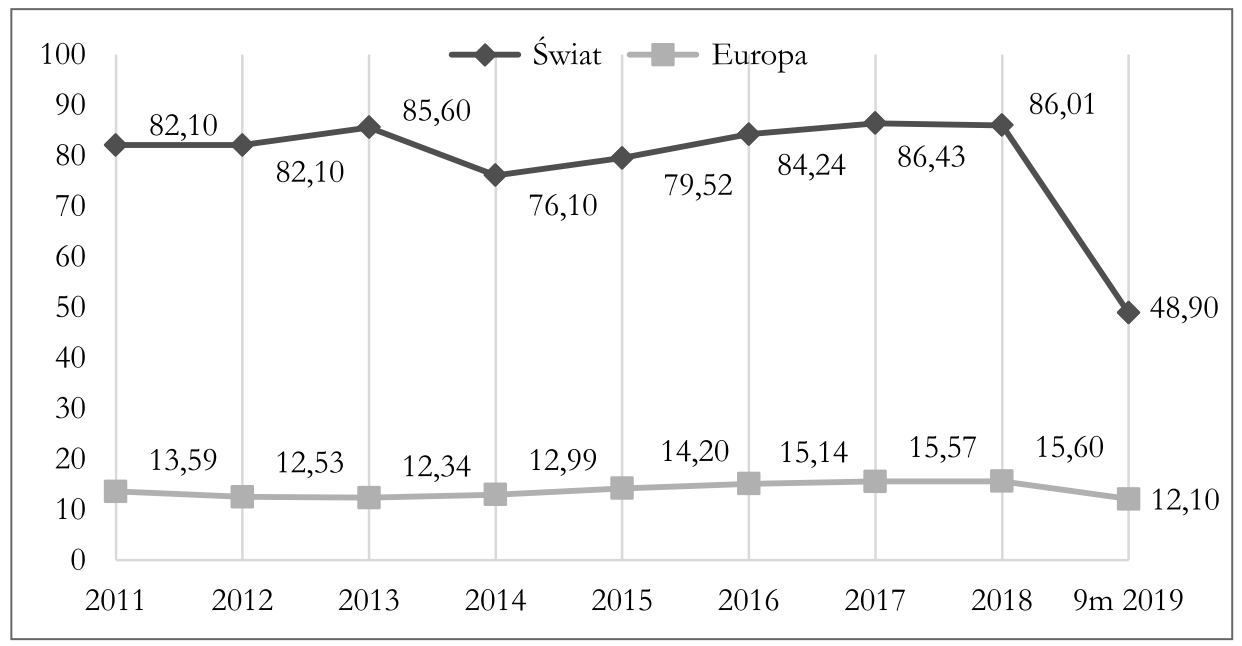

Rys. 1. Sprzedaż nowych samochodów na świecie i w Europie w latach 2011-Q3/2019 (mln sztuk)

Źródło: Opracowanie własne za: VDA Annual Report 2013, www.vda.de/en/services/Publications/ annual-report-2013.html/; VDA Annual Report 2014, www.vda.de/en/services/Publications/annual-report-2014.html/; VDA Annual Report 2015, www.vda.de/en/services/Publications/annual-report-2015.html (dostęp: 2.12.2019), JATO, Press Release: 27.01.2016; 19.01.2017; 9.02.2017; 29.01.2018; 20.02.2018; 30.01.2019; 21.02.2019.

W roku 2018 sprzedano 86 mln samochodów na 54 rynkach świata. Globalna sprzedaż obniżyła się o 0,5\% w stosunku do roku poprzedniego. Volkswagen, Toyota i Grupa Renault-Nissan zanotowali największe wolumeny sprzedaży. 


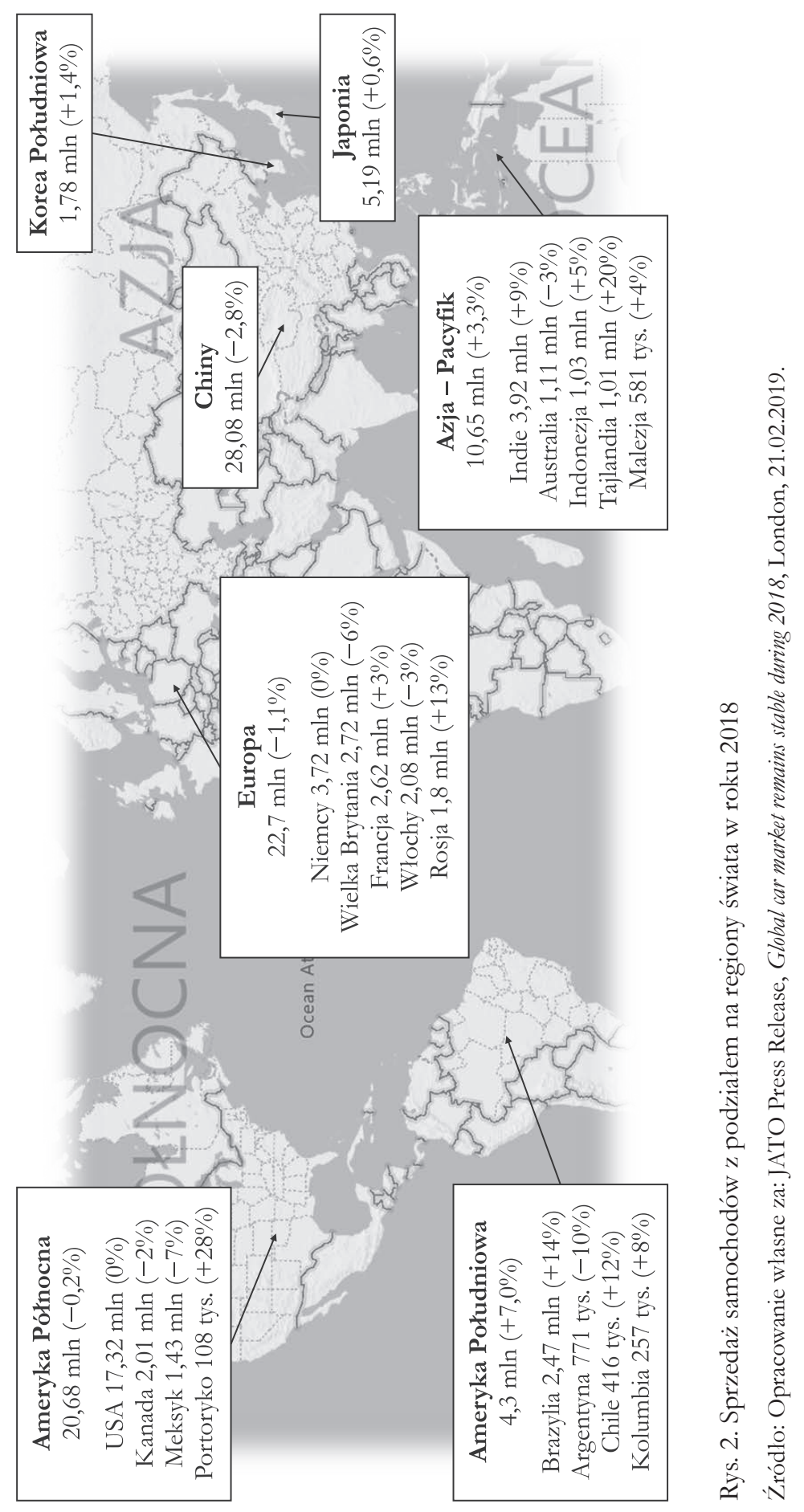


Sprzedaż samochodów typu SUV w liczbie 30 mln sztuk osiagnęła 36\% udziału w rynku sprzedaży nowych samochodów. Z kolei sprzedaż samochodów elektrycznych wzrosła w tym czasie o $74 \%$.

Rok 2018 był pełen wyzwań i problemów dla przemysłu motoryzacyjnego. Wiązało się to $\mathrm{z}$ różnymi napięciami w światowej gospodarce, zmianami politycznymi w głównych krajach czy niewiadomymi typowymi dla samej branży, która doświadcza nowych wyzwań wynikających nie tylko z postępującej globalizacji, ale też polityki państw, szczególnie w zakresie ochrony klimatu. Powołując się na słowa głównego analityka firmy JATO, Felipa Munoza, można określić rok 2018 jako początek nowej ery w przemyśle motoryzacyjnym ${ }^{19}$. Europa, Ameryka Północna i Chiny zanotowały wówczas spadek sprzedaży. Został on zrekompensowany częściowo przez wzrost sprzedaży na innych rynkach, takich jak: Indie, Brazylia, Rosja i Azja Środkowo-Wschodnia. Biorąc pod uwage wielkość rynku chińskiego, który odpowiada za 32,5\% całkowitej sprzedaży na świecie, jakiekolwiek wahania na tym rynku wpływają na wyniki sprzedaży ogółem.

W pierwszych 9 miesiącach 2019 r. jedynymi rynkami, na których zanotowano wzrost sprzedaży samochodów, były Brazylia i Japonia. Brazylia zanotowała największy wzrost sprzedaży ze wszystkich regionów na poziomie $8 \%$. Wzrost o 2,2\% w Japonii wiąże się ze wzrostem podatku na samochody w październiku 2019 r. i w związku z tym mało prawdopodobne jest utrzymanie go w czwartym kwartale 2019 r. Pozostałe rynki zanotowały spadek. Na rynku USA efekt spadku sprzedaży może być większy z uwagi na to, że w 2018 r. nie wykazał on wzrostu. Natomiast rynek indyjski i chiński zanotowały największy spadek sprzedaży. Na rynku indyjskim wiązało się to częściowo z polityką finansowania zakupu samochodów, natomiast jeśli chodzi o rynek chiński, utrzymała się występująca już wcześniej tendencja spadkowa, przy czym zmniejszenie sprzedaży o 2 mln sztuk było największe od $2015 \mathrm{r}$. Wynika to z ogólnego spowolnienia gospodarczego oraz z napięć na linii Chiny - USA. Co godne podkreślenia, mimo że Chiny zanotowały spadek w sprzedaży na poziomie aż 11,6\% w stosunku do analogicznego okresu roku poprzedniego, pozostają największym na świecie rynkiem sprzedaży samochodów osobowych.

Notując tak duży spadek sprzedaży na krajowym rynku, producenci chińscy zaczęli intensywniej szukać możliwości wejścia na inne rynki, na których byli obecni w dużo mniejszym stopniu. Takim rynkiem jest dla nich Europa z silnym przemysłem motoryzacyjnym. Konkurencja na tym obszarze jest dużym wezwaniem dla przedsiębiorstw z Państwa Środka.

19 JATO Press Release, Global car market remains stable during 2018, London, 21.02.2019. 
Tabela 1. Globalna sprzedaż nowych samochodów z podziałem na regiony w okresie 9 miesięcy $2019 \mathrm{r}$.

\begin{tabular}{|l|r|r|r|}
\hline \multicolumn{1}{|c|}{ Region } & Q1-Q3 2019 & Q1-Q3 2018 & Zmiana (\%) \\
\hline Europa (EU + EFTA) & 12115900 & 12304700 & $-1,6$ \\
\hline Rosja* & 1271400 & 1297400 & $-2,0$ \\
\hline USA* $^{*}$ & 12709100 & 12841700 & $-1,1$ \\
\hline Japonia & 3441200 & 3367300 & 2,2 \\
\hline Brazylia* & 1940200 & 1783000 & 8,8 \\
\hline Indie & 2177500 & 2605800 & $-16,4$ \\
\hline Chiny & 14963000 & 16922600 & $-11,6$ \\
\hline
\end{tabular}

* Pojazdy LV do 3,5 tony.

Źródło: Verband der Automobilindustrie, https://www.best-selling-cars.com/international/2019-latest-international-worldwide-car-sales/ (dostęp: 15.10.2019).

\section{Strategia chińskich producentów i ich konkurencyjność na rynku europejskim}

Chińskie koncerny motoryzacyjne usilnie poszukują możliwości szerszego zaistnienia na rynku europejskim. Od wielu lat stosują różne metody, by to osiagnąć, z czego najbardziej pożądane przez Europejczyków są inwestycje kapitałowe. Utrzymująca się od wielu lat duża nadwyżka chińskiego handlu zagranicznego spowodowała, że zmianie uległa polityka w zakresie jej wykorzystania. Korzystają na niej różne gałęzie gospodarki, które mają na celu rozwinięcie produkcji w kraju oraz ekspansje zagraniczna. Zyskuje na tym również przemysł motoryzacyjny, który po okresie zachęcania producentów europejskich do zakładania spółek joint-venture z chińskimi producentami w Chinach rozpoczął własny rozwój technologii w swoich zakładach. Wszystko to na bazie doświadczania i wiedzy zdobytej w ramach tej współpracy. Do tej pory Europejczycy korzystali na dostępie do chińskiego rynku, teraz chińscy producenci próbują wejść do Europy. Pomagają im w tym osoby, które pracowały wcześniej na kierowniczych stanowiskach u producentów znanych europejskich marek. Jednakże wysokie normy bezpieczeństwa na rynku europejskim oraz „obiegowa” opinia konsumentów o jakości chińskich produktów stanowią duże wyzwanie dla firm z Państwa Środka. Tymczasem nowe uwarunkowania prawne dotyczące norm jakości emisji spalin oraz kary z tym związane (począwszy od 2020 r.) stanowią kolejne istotne bariery dla chińskich producentów. Wiele lat temu przekonała się o tym marka Brilliance, która stała się znana w Europie za pośrednictwem niemieckiej spółki HSO Motors Europe. 
W 2003 r. Brilliance podpisał porozumienie z BMW w zakresie produkcji samochodów marki Sedan w Chinach. W roku 2006 do Europy rozpoczęto eksport modelu pod nazwą Zhonghua M1, który w następnym roku zmienił nazwę na Brilliance BS6. Z tym modelem wiążą się kłopoty producenta związane $\mathrm{z}$ wynikami crash testu, który wykazał duże niedoskonałości konstrukcji ${ }^{20}$. W 2007 r. niemiecki klub automobilowy ADAC przeprowadził testy zderzeniowe, które wypadły bardzo słabo - model nie uzyskał żadnej gwiazdki. Koncern szybko dopracował projekt BS6, jednakże nie poprawiło to znacząco wizerunku tego modelu na rynku.

Innym producentem, który zainwestował w produkcję samochodów w Europie, jest firma Great Wall, znana w Europie głównie za sprawą kontrowersyjnej kopii fiata pandy i wielu modeli bazujących na produktach Toyoty. Chińska firma wraz z bułgarskim Litex Motors zainwestowała w fabrykę $58 \mathrm{mln}$ euro. Samochody wytwarzane były z części oraz podzespołów dostarczanych bezpośrednio z Chin. Pomimo że w 2012 r. fabrykę opuścił pierwszy model testowy, firma nie zanotowała znaczących wielkości sprzedaży i koncern w 2017 r. zdecydował się ją zamknąć. Jednakże we wrześniu 2019 r. Great Wall zapowiedział ponowne rozważenie inwestycji w Europie, jeśli sprzedaż koncernu osiagnie 50 tys. sztuk rocznie. Potwierdził to prezes Wei Jianjun podczas ostatnich (wrzesień 2019 r.) targów motoryzacji we Frankfurcie ${ }^{21}$. Firma planuje rozpocząć w Europie sprzedaż modelu Wey SUV w ciagu najbliższych 2 lat. Sprzedaż będzie się opierać na modelach produkowanych już w Chinach, koncern nie zamierza kupować innej marki, aby się rozwijać na rynku europejskim, zwłaszcza że mógłby wspomagać się fabryką w Tuli (Rosja centralna) otwarta w czerwcu 2019 r. W fabryce tej produkowana jest marka Haval.

Kolejnymi producentami, którzy szukają przyczółków na kontynencie europejskim, są Chery, SAIC oraz Geely. Ten pierwszy nawiązał współpracę z włoską firmą DR Automobiles S.r.I. (dawniej DR Motor Company). DR Motor w 2006 r. założył Massimo Di Risio i do 2009 r. firma sprzedawała tylko we włoskich supermarketach. Od 2010 r. ma ona własną sieć dealerów i partnerów serwisowych. DR Motor zanotował w 2010 r. historyczną dla siebie wielkość sprzedaży samochodów na poziomie 5 tys. sztuk. Po tym roku sprzedaż znacząco spadła, osiagając w roku 2018 zaledwie 1,2 tys. sztuk. Chery we Włoszech rozwija podobny model produkcji jak firma Great Wall w Bułgarii, dostarczając własne komponenty z Chin. Na ich bazie, po pewnych modyfikacjach, firma włoska sprzedaje samochody pod marką DR. W 2019 r. rozpoczęła sprzedaż również w Hiszpanii oraz we Francji i Bułgarii. Prawdopodobnie firma Chery będzie rozwijać sprzedaż w Europie w oparciu o rozwój marki DR.

\footnotetext{
20 https://www.wnp.pl/motoryzacja/chinskie-firmy-przenosza-produkcje-do-europy,163404. html (dostęp: 2.12.2019).

21 https://europe.autonews.com/automakers/great-wall-mulls-building-cars-europe-again (dostęp: 1.09.2019).
} 
Siedziba koncernu Chery znajduje się w miejscowości Wuhu. Firma została założona w 1997 r., a już 10 lat później z linii montażowych wyjechał milionowy pojazd. W 2015 r. łączna produkcja wyniosła 5 mln samochodów. W Chinach Chery ma sześć zakładów produkcyjnych, a poza granicami swojego kraju dziesięć lokalizacji (na razie żadnej w Europie). Pod Frankfurtem mieści się centrum badawczo-rozwojowe koncernu (każdy z członków zespołu R\&D pracował wcześniej dla światowych potęg przemysłu motoryzacyjnego). Chery jest pierwszym chińskim koncernem motoryzacyjnym, który swoje produkty zaczął eksportować do innych krajów, zajmując pod tym względem pierwsze miejsce w rankingu. O jego sile eksportowej świadczy poniższe zestawienie.

Tabela 2. Eksport samochodów przez poszczególne chińskie koncerny w latach 2015-2018

\begin{tabular}{|l|l|l|r|l|r|l|r|}
\hline \multicolumn{2}{|c|}{2015} & \multicolumn{2}{c|}{2016} & \multicolumn{2}{c|}{2018} \\
\hline Chery & 86611 & Chery & 88081 & Chery & 107727 & Chery & 126993 \\
\hline Jac & 38217 & Jac & 38009 & Brillance & 47192 & AIC & 39852 \\
\hline Lifan & 35261 & Brillance & 32032 & Jac & 45360 & Jac & 35793 \\
\hline Geely & 28983 & Lifan & 30745 & Dongfeng & 35617 & Brillance & 35015 \\
\hline Great Wall & 16563 & Geely & 22611 & Lifan & 29376 & Great Wall & 29088 \\
\hline
\end{tabular}

Źródło: Opracowanie własne na podstawie materiałów wewnętrznych koncernu Chery.

Biorąc pod uwagę aktywność koncernu na innych kontynentach poza Europa (nie wliczając Rosji), w krótkim czasie powinniśmy spodziewać się większej ich aktywności na rynku europejskim. Krok w tym kierunku, chociaż dokonała go inna dywizja niż samochodów osobowych, już zrobiono. We wrześniu 2019 r. Chery Holdings Ltd. i Streetscooter GmbH podpisali umowę o współpracy. Wspólnie zamierzają zainwestować $500 \mathrm{mln}$ euro w Chinach na stworzenie centrum R\&D, które pozwoli produkować małe pojazdy elektryczne do przewozu paczek i listów ${ }^{22}$. Podstawowym założeniem jest produkcja 100 tys. pojazdów rocznie, a pierwszym klientem będzie SDeutsche Post AG, do której należy firma Streetscooter. Oba przedsiębiorstwa zamierzają nie tylko podbić swoje własne rynki, ale także zaoferować produkty globalnie.

Koncern Chery jest znany w Polsce jako niedoszły nabywca zakładów FSO. W Polsce nie udało się mu zaistnieć, ale za to zainwestował na Ukrainie i w Kaliningradzie, przejmując zakłady po Daewoo. Z obu zakładów Chery prowadzi sprzedaż na rynkach na wschód od naszej granicy. Kilka lat temu planował montaż pojazdów na Białorusi w państwowych zakładach MAZ, ale z planów nic nie wyszło. To, czego nie udało się Chery na Białorusi, w listopadzie 2017 r. dokonał inny

22 http://mobile.cheryinternational.com/web/home/news_data.html?table_id=1\&id=ddc8110ac55843629dbb49569033597e (dostęp: 4.12.2019). 
chiński koncern - Geely. We współpracy z drugim na świecie producentem maszyn górniczych firmą BelAZ i firmą Soyuz koncern utworzył joint venture pod nazwa BelGee. Celem przedsięwzięcia była budowa fabryki samochodów Geely w Borysewie, która miała produkować około 60 tys. sztuk rocznie ${ }^{23}$. Pierwszym rynkiem sprzedaży były Białoruś, Rosja i Ukraina. Firma ma w planie ekspansję na inne europejskie rynki, czego warunkiem jest uzyskanie homologacji na swoje produkty i spełnienie norm technologicznych. Trzeba przy tym podkreślić, że w Borysewie znajduje się jedyna fabryka Geely Auto Group poza Chinami. Auto Moto Group jest natomiast częścią struktury Geely Holding Group.

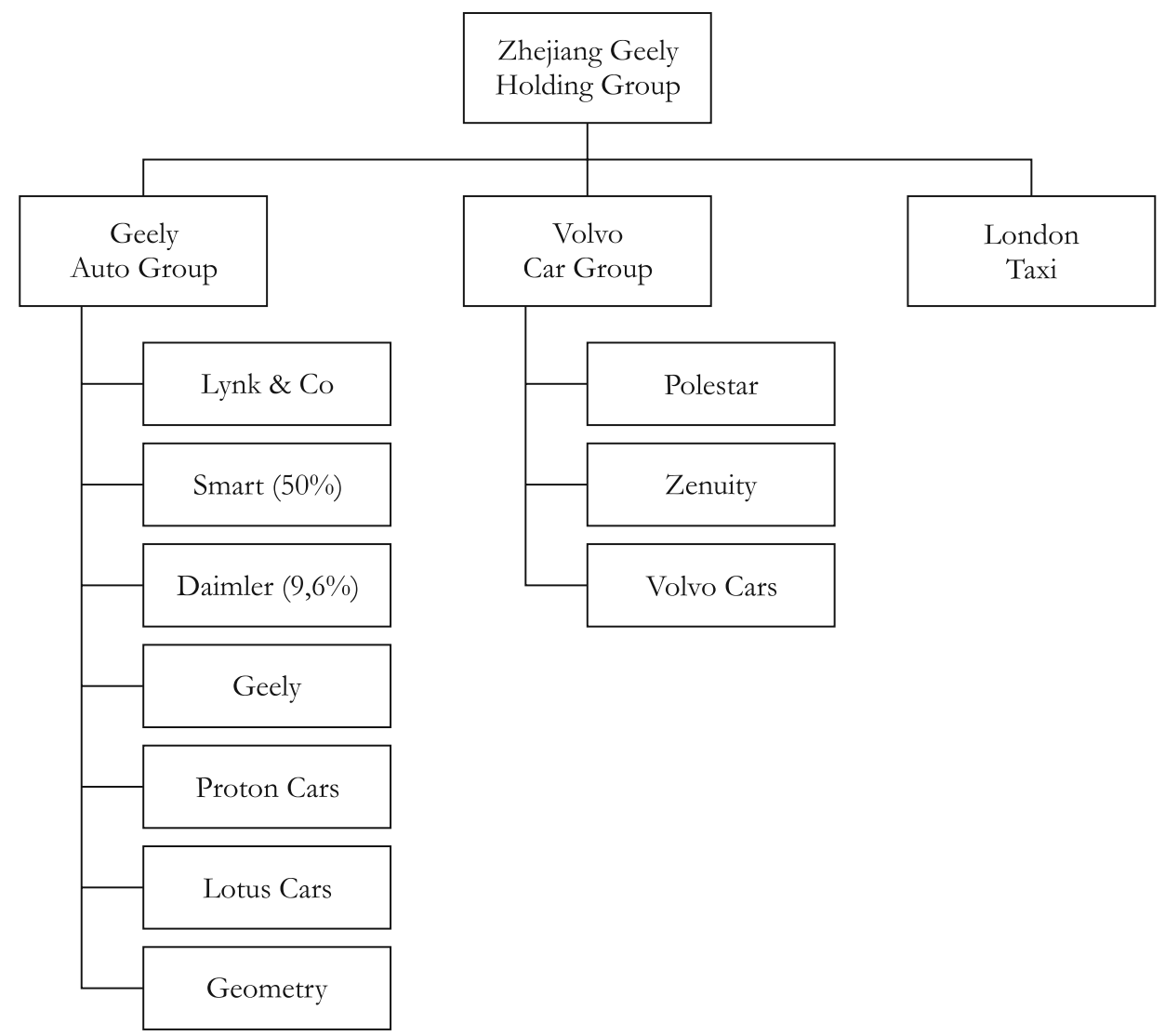

Rys. 3. Struktura Grupy Geely Holding

Źródło: Opracowanie własne na podstawie danych opublikowanych w „Auto Moto i Sport”, lipiec 2019, https://www.auto-motor-i-sport.pl/wydanie/07-2019,37153,5 (dostęp: 2.12.2019).

23 First „Atlas” from BELGEE Plant Roll Off Assembly Line, http://global.geely.com (dostęp: $5.12 .2019)$. 
Założycielem Geely jest chiński miliarder Li Shufu, wyceniany przez amerykańskiego Forbesa na 17,4 mld USD. Jego firma Geely Group początkowo produkowała części do lodówek, a następnie motocykle. W 1997 r. przestawiła się na samochody i obecnie jest największym producentem motoryzacyjnym w Chinach, niekontrolowanym przez państwo ${ }^{24}$. Strategia przedsiębiorstwa opiera się na zakupie pakietu akcji innych firm. W zależności od sytuacji jest to pakiet większościowy lub mniejszościowy. Pierwszym zakupem koncernu było szwedzkie Volvo.

W roku 2010 Geely kupiło Volvo Cars za 20\% ceny, jaką w 1999 r. Ford zapłacił za Volvo ${ }^{25}$. Pod koniec 2017 r. Geely zainteresowało się pozostałym działem, wytwarzającym ciężarówki pod nazwą Volvo Trucks i sfinalizowało w 2018 r. transakcję zakupu pakietu 14,9\% akcji. Transakcji dokonano za pomocą funduszu Cavian Capital ${ }^{26}$. Kosztowała ona koncern 3,3 mld USD ${ }^{27}$. Geely zdecydowało się na ten zakup po osiagnięciu zadowalających wyników przez Volvo Cars. Wpłynęło na to przede wszystkim pozytywne doświadczenie zdobyte we współpracy ze Szwedami oraz reputacja marki. Dokonując kolejnego zakupu, Chińczycy wspomogą rozwój nowych technologii, w szczególności samochodów elektrycznych i hybryd. Jest to obecnie kluczowe zagadnienie dla całej branży motoryzacyjnej.

Chiński koncern ma wobec Volvo ambitne plany. Do 2025 r. firma zamierza wyprodukować milion tzw. zelektryfikowanych samochodów (hybryd), a później także modeli wyłącznie z elektrycznym napędem. Volvo jako jedno z pierwszych podjęło decyzję o odejściu od silników diesla ${ }^{28}$. Inni producenci, jak np. Volkswagen, zakomunikowali, że ostatnia generacja silników TDI pojawi się na rynku około 2030 r. Takie podejście świadczy o innowacyjnym podejściu Geely, który ma aktualnie ambitniejsze plany niż jego konkurenci. Każdy z producentów stara się jak najszybciej wprowadzać nowe modele z napędem hybrydowym lub elektrycznym. Widoczne to było również na tegorocznych (2019) targach motoryzacyjnych IAA we Frankfurcie, gdzie producenci zaprezentowali swoje nowe modele aut. Biorąc pod uwagę nowe regulacje dotyczące redukcji emisji spalin, wchodzące w życie z początkiem 2020 r., trend ten jest nie do zatrzymania. Szwedzi swój pierwszy samochód elektryczny wprowadzą na rynek w maju 2020 r. pod marką Polestar. Stanowi on odpowiedź na samochód Tesli. Będzie to hybrydowe coupé z wtyczką z włókna węglowego o mocy ponad $600 \mathrm{KM}$ i momencie obrotowym 1000 niutonów. Plany Centrum Produkcji Polestar, zlokalizowanego w prowincji

${ }^{24}$ https://www.forbes.pl/biznes/li-shufu-i-jego-geely-group-kupuja-akcje-daimlera/g203ec2 (dostęp: 2.12.2019).

25 Do 1999 r. w Szwecji funkcjonowała tylko jedna firma pod nazwą Volvo AB. W 1999 r. dział wytwarzania samochodów osobowych został wyodrębniony pod nazwą Volvo Cars

26 https://www.reuters.com/article/us-geely-ab-volvo-purchase-idUSKBN1JE1WA (dostęp: 4.12.2019).

27 https://www.autocentrum.pl/newsy/geely-kupuje-volvo/ (dostęp: 4.12.2019).

28 https://www.auto-motor-i-sport.pl/wydanie/07-2019,37153,5 (dostęp: 2.12.2019). 
Chengdu, przewidują wyprodukowanie 500 sztuk modelu Polestar $1 \mathrm{w}$ pierwszym roku. Natomiast produkcja modelu Polestar 2 (sedan średniej wielkości) planowana jest na początek 2020 r. w fabryce Geely w prowincji Zhejiang, gdzie powstaja także modele pierwszych elektrycznych Volvo XC40 i crossoverów Lynk \& Co 01. Wszystkie trzy modele zostaną skonstruowane na platformie Volvo CMA (compact modular architecture $)^{29}$.

Właściciel Geely konsekwentnie realizuje politykę zakupu udziałów innych europejskich producentów. W 2018 r. zakupił 9,7\% akcji Daimlera, stając się jego największym akcjonariuszem. Udziały Daimlera warte 9 mld USD to największa chińska inwestycja za granicą w producenta motoryzacyjnego. Właściciel Geely ma nadzieję, że uda mu się w ten sposób skłonić Daimlera do współpracy technologicznej zwłaszcza w zakresie produkcji aut elektrycznych ${ }^{30}$. W Chinach Geely działa bez zagranicznych partnerów, natomiast Daimler współpracuje z konkurentami firmy: BAIC i BYD (wspieranym przez Warrena Buffetta). BYD Auto ma już swoje doświadczenia z samochodami elektrycznymi w Europie, ponieważ w Danii sprzedaje pierwsze auta elektryczne. O sile Geely świadczy fakt, że w jego portfelu znajduja się także inne europejskie firmy, takie jak London Taxi czy Lotus Cars (brytyjski producent samochodów sportowych).

Podobną strategię działania na rynku globalnym jak Chery ma inny chiński koncern - Shanghai Automotive Industry Corporation (SAIC). Koncern ten jako pierwsza firma państwowa utworzył joint venture z partnerem zagranicznym. Był to Volkswagen Group w roku 1983. Doświadczenie zdobyte z niemieckim partnerem pozwoliło na rozszerzenie współpracy o General Motors, z którym zostało utworzone kolejne joint venture w połowie lat 90. Po 20 latach bycia „,młodszym partnerem” SAIC stał się grupą o zasięgu międzynarodowym³1. W 2002 r. uczestniczył w zakupie koreańskiego producenta Daewoo przez General Motors (obecnie posiada 10\% udziału w kapitale), a w 2004 r. przejął kontrolę nad koreańskim producentem SsangYong Motor. Rok później SAIC przegrał walkę o przejęcie upadającego Rovera w Wielkiej Brytanii ze swoim konkurentem Nanjing Automobile Group (NAG), ale już 2 lata później sam go kupił. Wydaje się, że połączenie obu firm było nieuniknione i stanowiło efekt walki o przejęcie kontroli nad Roverem. Co ciekawe, w rękach SAIC były prawa autorskie do dwóch modeli Rovera 25 i 27 w Chinach, a w posiadaniu NAG był cały biznes MG Rover ${ }^{32}$. W efekcie po połaczeniu SAIC zyskał dostęp nie tylko do rynku europejskiego, ale przede wszystkim do działu R\&D zlokalizowanego w zakładach w Longbridge, w Birmingham.

\footnotetext{
29 https://europe.autonews.com/automakers/volvos-polestar-brand-begins-output-chengdu (dostęp: 2.12.2019).

30 https://www.forbes.pl/biznes/li-shufu-i-jego-geely-group-kupuja-akcje-daimlera/g203ec2 (dostęp: 2.12.2019).

31 https://www.hoerbiger.com/upload/file/02_12_saic_e.pdf (dostęp: 5.12.2019).

32 http://news.bbc.co.uk/2/hi/business/4708739.stm (dostęp: 5.12.2019).
} 
Warto podkreślić, że wspólną cechą wszystkich wymienionych producentów chińskich jest inwestowanie w nowy design modeli aut i działalność badawczo-rozwojowa. Taka polityka ma zapewnić lepsze zrozumienie wymagań rynkowych, pomóc w zdobyciu wiedzy na temat skomplikowanych tajników procesu homologacji i nawiązaniu współpracy z dostawcami. Według Stefana Bratzela, dyrektora Centrum Zarządzania Samochodowego na Uniwersytecie w Bergisch Gladbach w Niemczech, „te centra rozwojowe moga z pewnością przyczynić się do postępu technologicznego w Chinach. Moga być także dobrym punktem do wejścia na rynek europejski, jednakże producenci chińscy muszą zrozumieć, że ich produkty nie mają szans, jeśli nie będą spełniać wymagań europejskich"33.

Obserwując obecny trend w sprzedaży na rynku chińskim, widać, że po trzech dekadach wzrostu i wprowadzania dużego asortymentu samochodów na rynek krajowy, przyszedł czas na dostosowanie się do oczekiwań i wymagań klientów, którzy oczekują lepszej jakości, co oznacza koniec ery „niska cena, duża ilość” ${ }^{34}$. Jakość zastapiła kryterium ceny i ona jest głównym determinantem w przyszłych planach koncernów. Szczególnie widać to w planach rozwoju samochodów elektrycznych głównych producentów chińskich: Great Wall Motor, Geely, SAIC, Guangzhou i Chery. Po wykorzystaniu przewagi technologicznej i wcześniejszym rozpoczęciu produkcji samochodów elektrycznych w swoim kraju nadszedł czas na wyjście ze swoimi produktami na inne rynki, w tym europejski.

Od 2017 r. możemy zauważyć również znaczący spadek udziału samochodów z silnikiem diesla, większy aut benzynowych i z alternatywnym napędem, głównie z napędem elektrycznym (BEV). W 2018 r. w stosunku do 2017 udział diesla w rynku ogółem spadł o ponad 18\%. Tendencja ta utrzymała się w kolejnych trzech kwartałach 2019 r., pogłębiając spadek o kolejne 16\%. W analogicznych okresach popyt na samochody z silnikiem spalinowym wzrósł kolejno o 12,4\% i 3,1\%. Udział silników benzynowych i diesla wyniósł łącznie 90\% ogółem. Pozostały udział miały samochody z napędem hybrydowym oraz alternatywnym. W grupie pojazdów z alternatywnym napędem udział plug-in (PHEV) spadł w trzech kwartałach 2019 r. o prawie $13 \%$.

Obecne spowolnienie na chińskim rynku motoryzacyjnym, które trwa od kilkunastu miesięcy, stanowi główną motywację do przyspieszenia prac mających za cel wyjście poza Chiny. Dodatkowo, wprowadzenie bardziej restrykcyjnych standardów emisji „C6” w wielu rejonach Państwa Środka oraz napięcia handlowe z USA spowodowały rewizje prognoz sprzedaży do 2025 r. Dlatego też eksport wydaje się jedyną nadzieją dla chińskich producentów. Na tym tle bycie konkurencyjnym,

\footnotetext{
33 https://europe.autonews.com/automakers/chinese-automakers-use-europe-based-rdcenters-springboard-bigger-plans (dostęp: 5.12.2019).

34 https://www.scmp.com/business/china-business/article/2086754/four-brands-dominate-chinas-automotive-oligopoly (dostęp: 5.12.2019).
} 


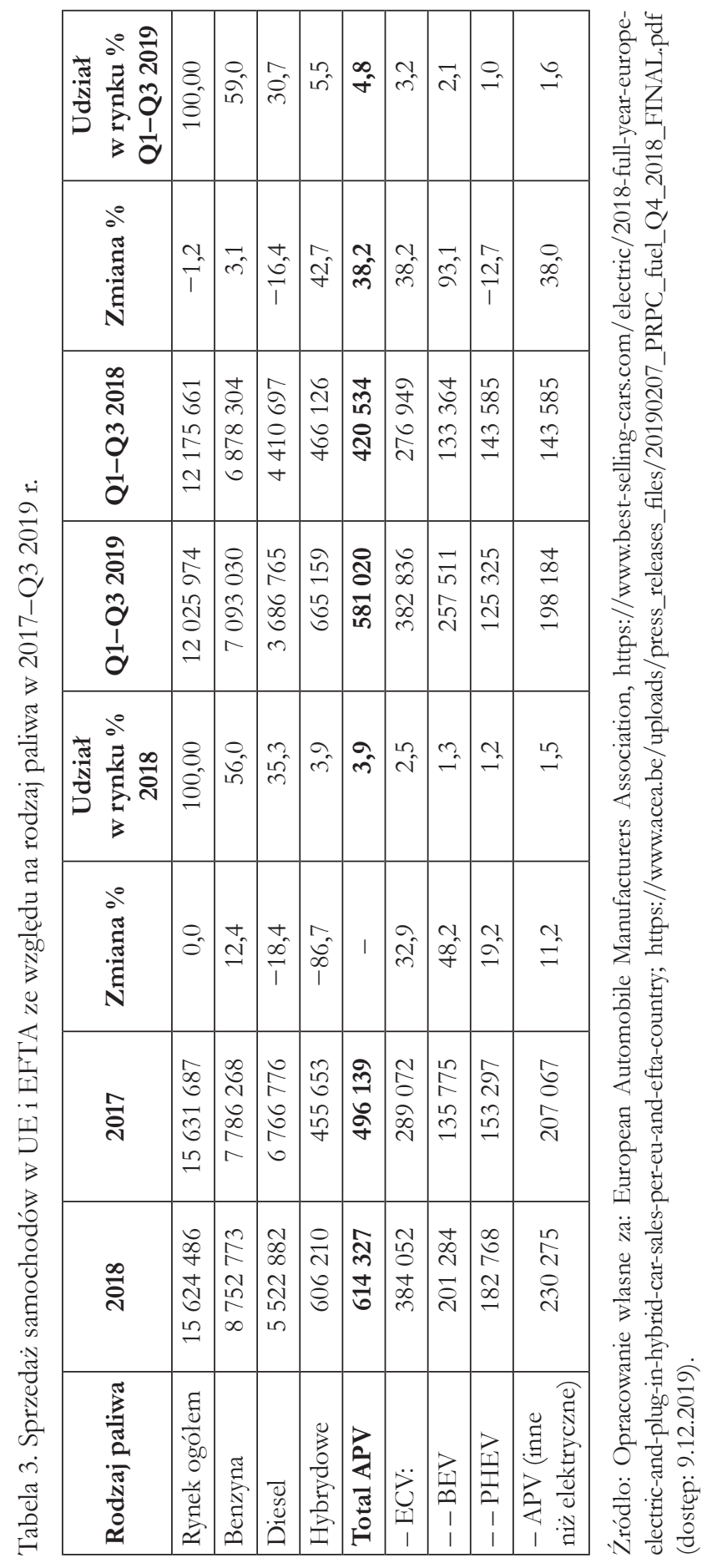


poruszanie się już w obszarze przewagi konkurencyjnej na bazie doświadczeń, technologii oraz postawienie na jakość kosztem ceny, adaptacja do restrykcyjnych europejskich norm czy utrwalanie tej przewagi w efekcie posiadania dużych możliwości kapitałowych przez chińskich producentów wydaje się zadaniem do zrealizowania w perspektywie nadchodzaccych lat. Wszystkie te elementy zestawione razem moga spowodować, że rynek samochodów elektrycznych w Europie zostanie zdominowany przez chińskie firmy.

\section{SUMMARY \\ COMPETITIVENESS AND PRACTICAL ACTIVITIES OF CHINESE PRODUCERS OF ELECTRIC CARS ON THE EUROPEAN MARKET}

Competition in the automotive market is generally known and described. This market is dominated by the large players who have been operating for a long time. Environmental protection is directly linked to natural resources and means that competition is moving towards electrical vehicles. This new sector seeks a competitive advantage to succeed on the market.

The aim of this article is to assess the chances of Chinese electric car manufacturers on the European market. In order to achieve this goal the method of analysis and synthesis in the field of competitiveness and competitive advantage was used. The case study method was also used to refer to the practice of Chinese car producers in China and Europe.

The data gathered leads to the conclusion that Chinese manufacturers are well aware of how to build up competitiveness in Europe. They know how to gain and maintain areas of competitive advantage. Purchase of a stake in European producers or some other kind of cooperation with them means that the presence of Chinese electric vehicle producers on the European market is becoming substantial. After years of learning, the time of expansion has arrived, which, as collected data show, has every chance of being successful. 